\title{
Syzygium aromaticum extracts as good source of betulinic acid and potential anti-breast cancer
}

\author{
Abdalrahim F. A. Aisha, ${ }^{1}$ Khalid M. Abu-Salah, ${ }^{2}$ Salman A. \\ Alrokayan, ${ }^{2}$ Mohammad J. Siddiqui, ${ }^{1}$ Zhari Ismail, ${ }^{1}$ Amin \\ Malik Shah Abdul Majid ${ }^{*}$
}

${ }^{1}$ School of Pharmaceutical Sciences, Universiti Sains Malaysia, Malaysia,

${ }^{2}$ The Chair of Cancer Targeting and Treatment, Biochemistry Department and King Abdulla Institute for Nanotechnology, King Saud University, Saudi Arabia.

\begin{abstract}
Syzygium aromaticum (L.) Merr. \& L.M. Perry, Myrtaceae, is an evergreen tree with anticarcinogenic, antimutagenic, aphrodisiac, antimicrobial, antioxidant and antiinflammatory properties. This study aims to investigate the anti-breast cancer effect of extracts from leaves, stem and bark of $S$. aromaticum and to develop a method for preparation of betulinic acid fraction from the leaves. Betulinic acid, ursolic acid and oleanolic acid contents of the extracts were determined by HPLC. A betulinic acid fraction was prepared by simple crystallization of leaves extract and was characterized by HPLC and mass analysis. Anti-breast cancer effects were studied on MCF-7 and MDA-MB-231 cells. The extracts were found to contain high levels of betulinic acid particularly the leaves extract which contained $17 \%$ wt $/$ wt. The betulinic acid fraction contains $75 \%$ betulinic acid. Cytotoxicity testing reveals high and selective cytotoxic effect of the stem extract on MCF-7 cells with IC50 $33 \pm 1.6 \mu \mathrm{g} / \mathrm{mL}$. Cytotoxic effect of the stem extract was due to activation of apoptotic machinery of cell death. Combination studies of stem extract with tamoxifen reveals antagonistic effect at high concentration of tamoxifen and enhancement effect at low concentration. The selective cytotoxicity of the stem extract of $S$. aromaticum on MCF-7 is not due to betulinic acid but due to other constituents yet to be discovered.
\end{abstract}

Revista Brasileira de Farmacognosia Brazilian Journal of Pharmacognosy 22(2): 335-343, Mar./Apr. 2012

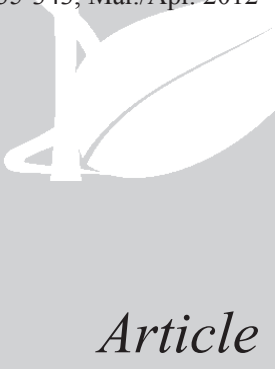

Received 30 Nov 2010

Accepted 7 Mar 2011

Available online 7 Oct 2011

Keywords: apoptosis betulinic acid breast cancer Syzygium aromaticum tamoxifen

ISSN 0102-695X http://dx.doi.org/10.1590/S0102$695 \times 2011005000185$

\section{Introduction}

Syzygium aromaticum (L.) Merr. \& L.M. Perry (SA) is an evergreen tree from the family Myrtaceae. The tree is cultivated in most tropical countries including Malaysia, Indonesia, Zanzibar, India, and Sri Lanka. The essential oil obtained from the dried flower buds of SA (clove) has been used since ancient times in traditional medicine, perfume industry and in flavorings (Zheng et al., 1992). Traditional uses of clove oil include treating burns, dental care to relieve pain and to treat gum infections when used at high concentrations (Prashar et al., 2006), and to treat respiratory and digestive problems (Banerjee et al., 2006). Phytochemical studies showed eugenol, eugenol acetate, caryophyllene, and sesquiterpenes as the main constituents of clove essential oil (Zheng et al., 1992; Chaieb et al., 2007).

Previous research on SA includes remarkable biological properties such as anticarcinogenic (Zheng et al., 1992), antimutagenic (Miyazawa \& Hisama, 2001) aphrodisiac (Tajuddin et al., 2004), mosquito repellent (Trongtokit et al., 2005), cytotoxicity on human fibroblasts and endothelial cells (Prashar et al., 2006), antimicrobial (Chaieb et al., 2007), chemopreventive agent for lung cancer (Banerjee et al., 2006), antioxidant (Ogata et al., 2000), antiangiogenic (Aisha et al., 2011) and antiinflammatory (Darshan \& Doreswamy, 2004).

Betulinic acid (BA), oleanolic acid (OA) and ursolic acid (UA) are pentacyclic triterpenes of natural origin isolated from various plants (Jäger et al., 2009). Recently the compounds have gained considerable interest because of their multiple pharmacological effects including anti-HIV (Fujioka et al., 1994), antibacterial (Mutai et al., 2009), antiviral (Pavlovaa et al., 2003), anticancer (Fulda, 2008), antiangiogenic (Mukherjee et al., 2004) and antiinflammatory activities (Viji et al., 2010).

This study was undertaken to investigate the anti-breast cancer effect of three extracts from the leaves, stem and bark of $S$. aromaticum. The study also aims to develop a process for preparation of BA fraction from the leaves extract and to determine betulinic acid, ursolic 
acid and oleanolic acid contents of the crude extracts. The motivation behind this study was to highlight the importance of SA as a good source of BA and its significance as a potential anti-breast cancer agent.

\section{Materials and Methods}

\section{Chemicals}

DMEM cell culture medium and fetal bovine serum were obtained from GIBCO, USA. BA, UA, OA, tamoxifen, penicillin/streptomycin solution, XTT reagent, phenazine methosulfate (PMS) and Hoechst 33258 were purchased from Sigma. Solvents of either HPLC or analytical grade were purchased from Merck. Caspase 3/7 kit was purchased from Promega.

\section{Plant material and extraction}

Fresh leaves, bark and stems of Syzygium aromaticum (L.) Merr. \& L.M. Perry, Myrtaceae, were collected from the botanical garden of School of Pharmaceutical Sciences, USM during December 2009. The plant was authenticated by Mr. Shanmugan A/C Vellosamy, Herbarium of School of Biological Sciences, where a voucher specimen (11208) was deposited for reference. The dried and grinded plant material was extracted exhaustively in methanol by Soxhlet extractor for $48 \mathrm{~h}$. Methanol was evaporated at $50{ }^{\circ} \mathrm{C}$ under reduced pressure and the extracts were saved in air tight containers until use. The percent yield (wt/wt) was calculated relative to the plant dry weight which was $12 \%$ (leaves), 9\% (stem) and 8\% for bark extract.

\section{Preparation of BA fraction from leaves extract of $S A$}

Dried leaves $(40 \mathrm{~g})$ were extracted in methanol as mentioned above. The dried methanolic extract was washed three times with ice-cold methanol at 10:1 v/ wt, and the solid material was collected each time. The resulting solid material was crystallized in 4:1 methanol: $n$-hexane at room temperature by solvent evaporation. $600 \mathrm{mg}$ of needle shaped crystals was obtained. The BA content of the crystals was analyzed both qualitatively and quantitatively by HPLC and direct infusion electrospray mass spectrometry (ESI-MS) as described in the next section.

\section{Direct-infusion electrospray mass spectrometry}

Mass spectra were obtained using a LC-MSDTrap-VL Electrospray ion (ESI) mass spectrometer (Agilent Technologies) in direct infusion mode. The samples were prepared in HPLC grade methanol and were injected directly into the ESI source at a flow rate of
$5 \mu \mathrm{L} / \mathrm{min}$. The MS conditions were as follows: negative ion mode; gas (N2) temperature, $325^{\circ} \mathrm{C}$; flow rate, 5.0 $\mathrm{L} / \mathrm{min}$; nebulizer pressure, $15 \mathrm{psi}$; $\mathrm{HV}$ voltage, $4.0 \mathrm{kV}$; octopole RF amplitude, $150 \mathrm{Vpp}$; skim 1 voltage, -38.8 $\mathrm{V}$; skim 2 voltage, $-6.0 \mathrm{~V}$; capillary exit, $-113.8 \mathrm{~V}$; cap exit offset, $-75.0 \mathrm{~V}$; and scan range, $\mathrm{m} / \mathrm{z}$ 350-550 units. Acquired mass spectra represented the average of five spectra.

\section{Quantitative determination of $B A, U A$ and $O A$ by HPLC}

BA, OA and UA content of the extracts was determined quantitatively by HPLC (Agilent 1100) according to a previously published method with some modifications (Srivastava \& Chaturvedi, 2010). Analytical chromatography was carried out using a reverse phase Zorbax Eclipse Plus C18 (5 $\mu \mathrm{m}, 4.6$ x $250 \mathrm{~mm}$ ) column. The mobile phase consisted of A (acetonitrile), B $(0.1 \%$ $\mathrm{H}_{3} \mathrm{PO}_{4}$ in water). The elution program was isocratic at $86 \% \mathrm{~A}$ and $14 \% \mathrm{~B}$ for $20 \mathrm{~min}$. The flow rate was maintained at $1 \mathrm{~mL} / \mathrm{min}$ and the injection volume was 10 $\mu \mathrm{L}$. The spectral data from the UV detector was collected mainly at $210 \mathrm{~nm}$ (in addition to 230 and $254 \mathrm{~nm}$, for BA fraction) and data acquisition was performed by ChemStation version A.08.03. The calibration curves of BA, UA and OA reference compounds were constructed by plotting the peak area versus concentration. The resulting linear regression equations were applied to calculate the concentration of each particular triterpene in the samples. The results are presented as wt/wt percentage using the formula: (the calculated concentration/loaded concentration) X $100 \%(n=3)$.

\section{Cell lines and cell culture}

MCF-7 human estrogen dependent breast cancer and MDA-MB-231 human estrogen independent breast cancer cell lines (ATCC) were cultured as monolayer in DMEM containing 10\% fetal bovine serum and $1 \%$ penicillin/streptomycin at $37{ }^{\circ} \mathrm{C}$ in a humidified atmosphere of $5 \% \mathrm{CO}_{2}$.

\section{Cytotoxicity testing}

Cytotoxic effect of extracts was evaluated using 2,3-bis[2-methyloxy-4-nitro-5-sulfophenyl]-2Htetrazolium-5-carboxanilide (XTT) assay as described previously (Jost et al., 1992; Aisha et al., 2009a). Briefly, cells were seeded in 96-well plates and incubated for overnight to allow attachment. Cells were treated with different concentrations of extracts, positive control (tamoxifen) or vehicle (DMSO). After $48 \mathrm{~h}$ treatment, cell's viability was assessed by XTT test. The optical density was measured at $450 \mathrm{~nm}$, and the percent viability was calculated using the formula (absorbance of samples 
- blank)/(absorbance of negative control - blank) x 100\%. The experiment was repeated three times and the results were presented as average $\pm \mathrm{SD}$.

\section{Effect on caspases 3/7 of MCF-7 cells}

Effect of stem extract on caspases $3 / 7$ was studied as described in our previous publication (Aisha et al., 2009b). Briefly, 3 x $10^{4} \mathrm{MCF}-7$ cells were seeded in $200 \mu \mathrm{L}$ medium. On the next day, the old medium was replaced with $100 \mu \mathrm{L}$ fresh one containing different concentrations of extract. After $6 \mathrm{~h}$ treatment, caspase $3 / 7$ reagent was added at $1: 1(\mathrm{v} / \mathrm{v})$ and further incubated for $30 \mathrm{~min}$ at room temperature. Luminescence was measured and the results are presented as mean of relative light units $(\mathrm{RLU}) \pm \mathrm{SD}(\mathrm{n}=4)$.

\section{Nuclear staining with Hoechst 33258}

Nuclear staining with Hoechst 33258 was performed as previously described (Cheah et al., 2006; Chen et al., 2008). Briefly, treated and untreated cells were washed with phosphate buffered saline (PBS) followed by incubation in $10 \mu \mathrm{g} / \mathrm{mL}$ Hoechst 33258 solution at room temperature for $20 \mathrm{~min}$. At the end of incubation, cells were washed extensively with PBS and nuclear morphology was examined under IX 71 fluorescent microscope (Olympus, Japan). To quantify the apoptotic index, the percentage of single and multi intense-fluoresced cells (apoptotic morphology) were calculated from five random microscopic fields at $\times 20$ magnifications.

\section{Combination with tamoxifen}

Effect of combination of the stem extract with tamoxifen on viability of MCF-7 cells was studied by XTT as explained above. The experiments were designed to study the effect of simultaneous and sequential treatment (See the diagram below).

In the first experiment MCF-7 cells were treated for $48 \mathrm{~h}$ with tamoxifen at $10 \mu \mathrm{g} / \mathrm{mL}$, stem extract at $25 \mu \mathrm{g} / \mathrm{mL}$ and the combination of both. In the second experiment the cells were treated with tamoxifen at 10 $\mu \mathrm{g} / \mathrm{mL}$ or the extract at $25 \mu \mathrm{g} / \mathrm{mL}$ for $24 \mathrm{~h}$. Then the first drug was removed and cells were treated with the other drug (cross match) for further $24 \mathrm{~h}$. In the third experiment MCF-7 cells were treated for $48 \mathrm{~h}$ with tamoxifen at $5 \mu \mathrm{g} /$ $\mathrm{mL}$ or the extract at different concentrations 50, 40 and $25 \mu \mathrm{g} / \mathrm{mL}$, and the combination of both. Then viability of cells was determined and the percent of inhibition was calculated for each treatment alone and the combination.

\section{Statistical analysis}

The results are presented as mean $\pm \mathrm{SD}$. Differences between groups were analyzed either by student t-test or One way ANOVA, and differences were considered significant at $\mathrm{p}<0.05$.

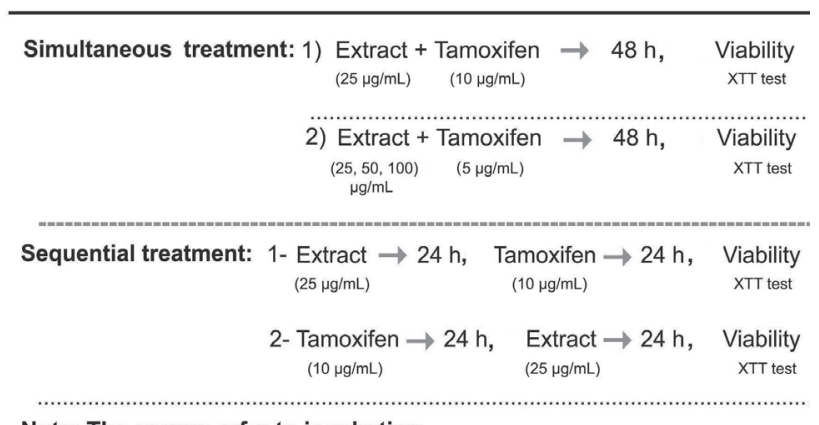

Note: The arrows refer to incubation

Schematic diagram explaining the combination experiment with tamoxifen.

\section{Results}

\section{Preparation of BA fraction}

BA fraction was prepared successfully in a simple process from the methanolic extract of SA leaves. The wt/wt percentage yield, to the dry plant material, was satisfactory $(1.5 \% \mathrm{wt} / \mathrm{wt})$. In previous study we showed that methanolic extracts of SA are rich in polyphenols (Aisha et al., 2011), which are highly soluble in methanol. Principally, the preparation of BA fraction is based on the different solubility patterns of triterpenes including BA and the polyphenols content of the extract. In cold methanol the triterpenes are highly insoluble whereas the polyphenols are highly soluble. Therefore the solid residue that remains after washing with cold methanol will contain high contents of triterpenes. The purity is increased by repeated washing and by further crystallization in 4:1 methanol: $n$-hexane. Since BA has remarkable pharmacological properties and since $S$. aromaticum is widely available in most Asian countries, this process has a potential for commercial and medicinal applications.

\section{Identification of $B A$}

$\mathrm{BA}$ in the BA fraction prepared from the leaves extract of SA was primarily identified by comparing the HPLC retention time with that of BA standard (Figure 1A, B). Afterwards, the MS analysis was performed which further confirmed the identity of BA. Figure 1C and D shows the mass spectrum of the standard BA and BA fraction. The same peaks for both BA standard and the BA fraction were obtained at $m / z$ 455.3, 456.1 and 457.1 which correspond to the different isotopic patterns of BA and confirm the identity of prepared BA. 


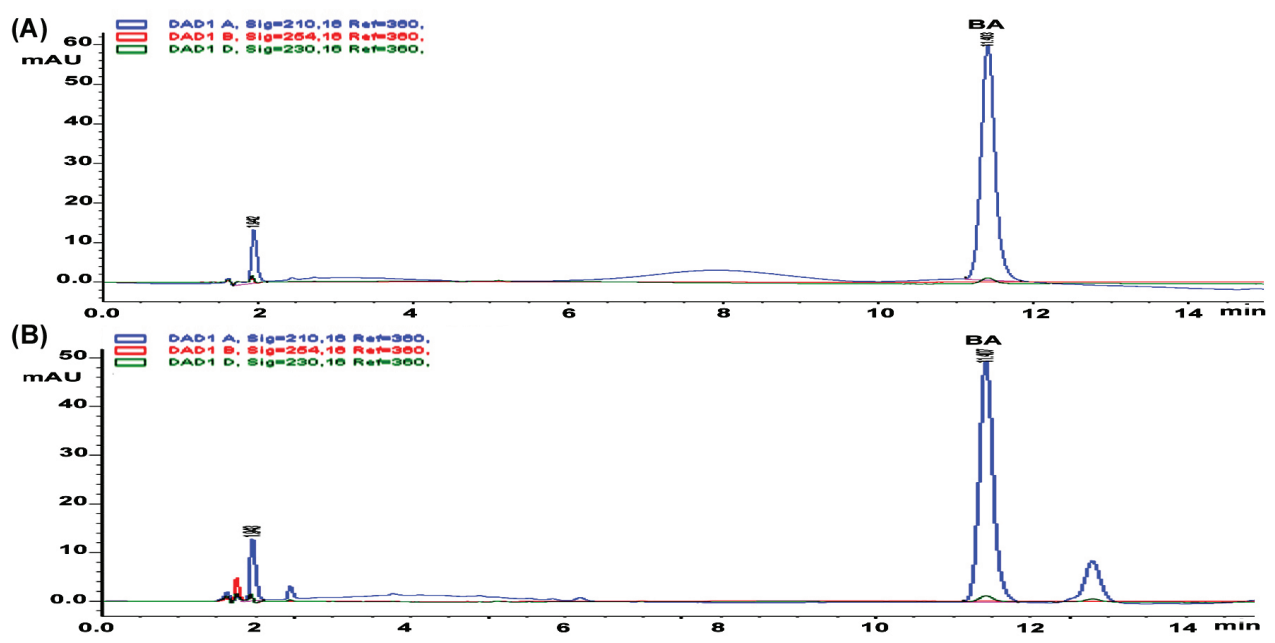

(C)

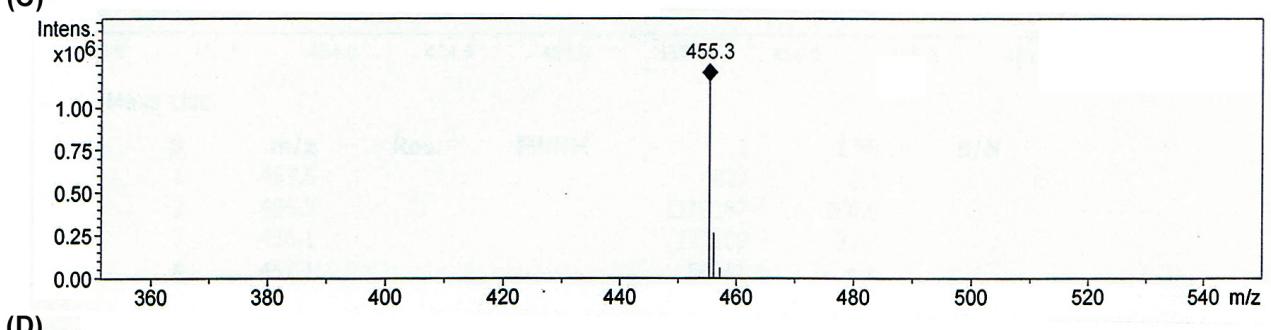

(D)

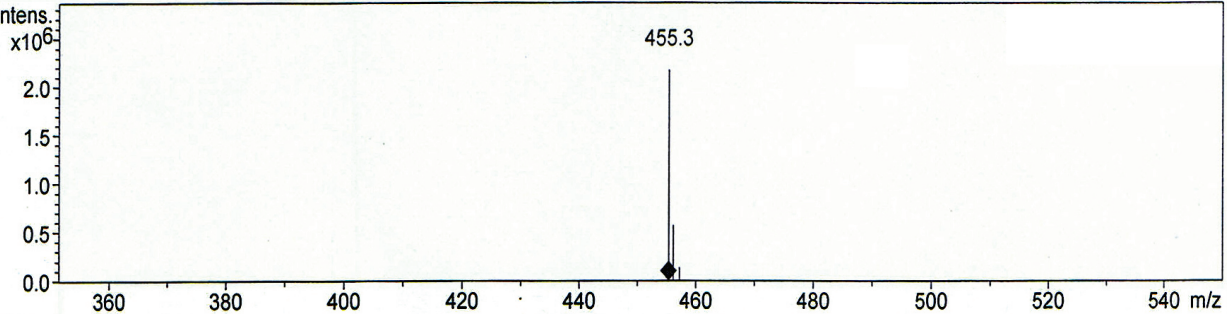

Figure 1. Identification of BA fraction prepared from methanolic extract of Syzygium aromaticum; HPLC chromatograms of BA standard (A), BA fraction from $S$. aromaticum (B), mass spectrum of BA standard (C), and BA fraction from $S$. aromaticum (D). The results indicate BA as the main component of BA fraction and other compound has the same mass of BA.

Quantification of $B A, U A$ and $O A$ in $S A$ extracts and $B A$ fraction

The extracts were analyzed by HPLC for the presence of BA, UA and OA. HPLC chromatograms are shown in Figure 2 and indicate the presence of the aforementioned triterpenes. Then concentration of BA, $\mathrm{UA}$ and $\mathrm{OA}$ in the extracts was determined quantitatively by applying the linear regression equations of reference compounds (Table 1). The results as wt/wt percentage indicate $\mathrm{BA}$ as the main triterpene component of the extracts followed by UA, and lesser amounts were found for OA (Table 1). The highest levels of BA were obtained in the leaves extract. Quantitative analysis of BA in BA fraction indicates the presence of $\mathrm{BA}$ at $75 \pm 0.2 \% \mathrm{wt} / \mathrm{wt}$ and $\mathrm{OA}$ at $15 \pm 0.4 \% \mathrm{wt} / \mathrm{wt}$.
Stem extract exhibited selective cytotoxicity on $M C F-7$ cells

Cytotoxicity testing of the extracts was done by XTT assay firstly on MCF-7 cells. The three extracts reduced viability of $\mathrm{MCF}-7$ cells in a dose dependent manner. IC50 values were calculated from the dose response curves and indicate the stem extract as the most potent with IC50 $33 \pm 1.6 \mu \mathrm{g} / \mathrm{mL}$. Extracts from bark and leaves were less active with IC50 $38 \pm 0.9$ and $69 \pm 0.7 \mu \mathrm{g} /$ $\mathrm{mL}$, respectively. IC50 of BA fraction and tamoxifen were $47 \pm 1$ and $8.2 \pm 0.5 \mu \mathrm{g} / \mathrm{mL}$, respectively. Then we studied cytotoxicity of stem extract on MDA-MB-231 cells. The extract was less cytotoxic on MDA-MB-231 compare to MCF-7 cells; the calculated IC50 was $79 \pm 3$ $\mu \mathrm{g} / \mathrm{mL}$ (Figure 3). 

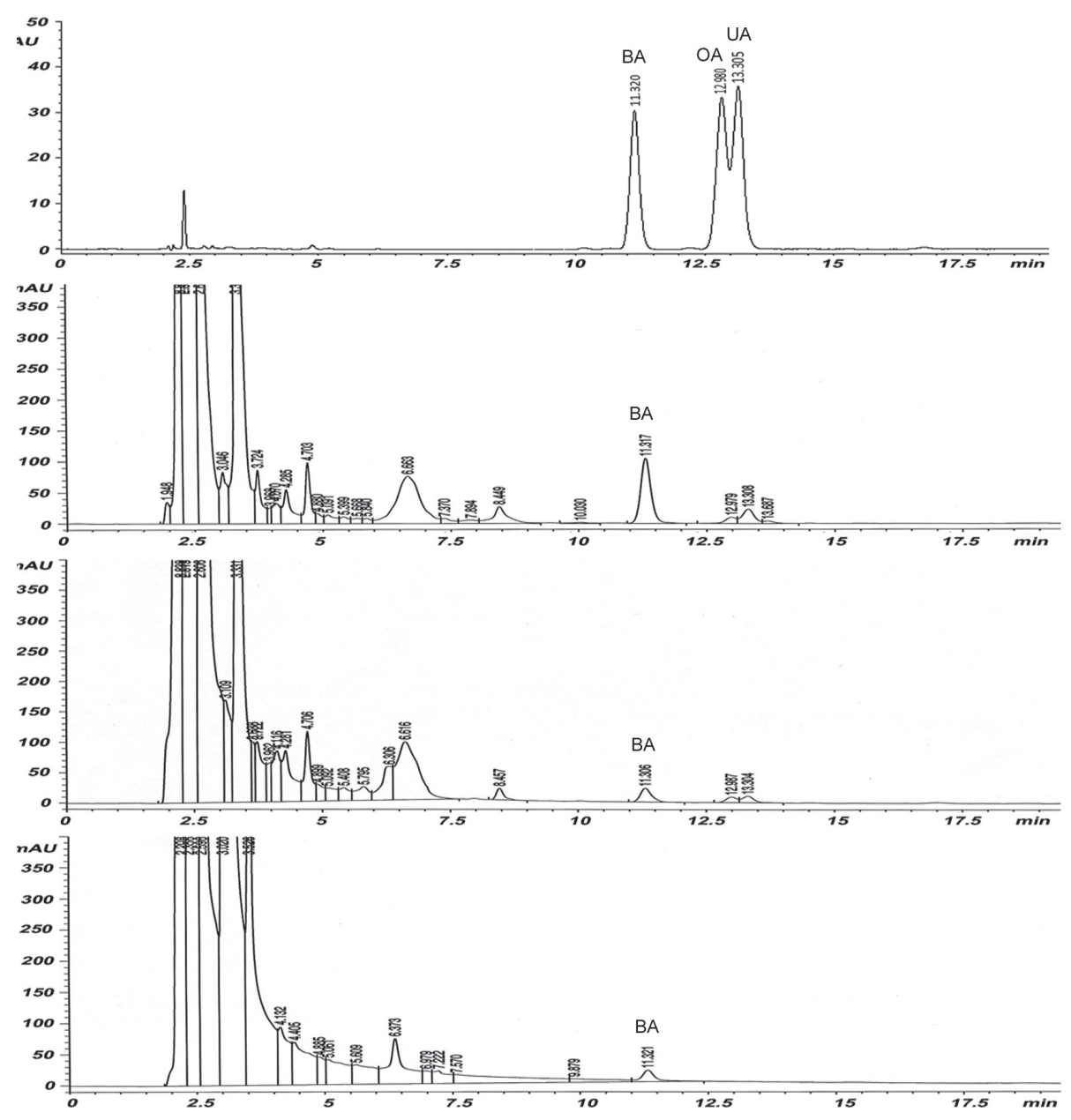

Figure 2. Comparison of HPLC chromatograms of leaves, stem, and bark extracts of Syzygium aromaticum. Chromatograms of the standard mixture consisting of BA, UA and OA (A), leaves extract (B), stem extract (C) and the bark extract (D). The results indicate the highest level of BA is obtained in leaves extract.

Table 1. Triterpenes content of the leaves, stem and bark extracts of Syzygium aromaticum. The results are presented as wt/wt percentage \pm SD.

\begin{tabular}{|c|c|c|c|c|}
\hline Compound & Leaves & Stem & Bark & $\begin{array}{l}\text { Calibration } \\
\text { equations }\end{array}$ \\
\hline Betulinic acid & $16.9 \pm 0.9$ & $3.5 \pm 0.2$ & $3.8 \pm 0.4$ & $\begin{array}{c}\mathrm{y}=0.8336 \mathrm{x}+76.1 \\
\mathrm{R} 2=0.9598\end{array}$ \\
\hline Ursolic acid & $3.7 \pm 0.7$ & $3.5 \pm 0.04$ & Nil & $\begin{array}{c}y=1.3417 x+119.4, \\
\quad R 2=0.9703\end{array}$ \\
\hline Oleanolic acid & $3.0 \pm 0.3$ & $0.9 \pm 0.05$ & Nil & $\begin{array}{c}y=0.9945 x+92.8 \\
R 2=0.9704\end{array}$ \\
\hline
\end{tabular}

Stem extract induced caspases 3/7 activity

Effect of stem extract on the early markers of apoptosis namely caspases 3/7 was evaluated on MCF-7 cells after $6 \mathrm{~h}$ treatment with the extract or tamoxifen. The extract enhanced the activity of the executioner caspases in a dose dependent manner (Figure 4). Compare to untreated cells, significant activation of caspases $3 / 7$ was obtained at $50 \mu \mathrm{g} / \mathrm{mL}$ and above, $p$ values $=0$, and no significant effect was achieved at $25 \mu \mathrm{g} / \mathrm{mL}, p>0.05$.

\section{Nuclear staining with Hoechst 33258}

MCF-7 cells were treated for $6 \mathrm{~h}$ with four concentrations of stem extract versus the vehicle as a negative control and tamoxifen at $10 \mu \mathrm{g} / \mathrm{mL}$ as a positive control. Figure 5 reveals clear apoptotic morphology of treated cells characterized by a single intense or multiple strong fluorescent signals of stained nuclei. By analysis of the fluorescence images, shrinkage of cells and plasma membrane convolution were all observed in the treated cells. The control culture (untreated cells) was uniformly stained with no substantial fluorescence signal. The calculated apoptotic indexes indicate dose dependent induction of apoptosis by the stem extract. Apoptotic indexes of treated cells were compared to untreated cells by One way ANOVA. The results indicate significant induction of apoptosis with tamoxifen and the extract at 
100,75 , and $50 \mu \mathrm{g} / \mathrm{mL}, p$ values $<0.05$. No significant difference was found between the treated cells at $25 \mu \mathrm{g} /$ $\mathrm{mL}$ and untreated cells, $p>0.05$.
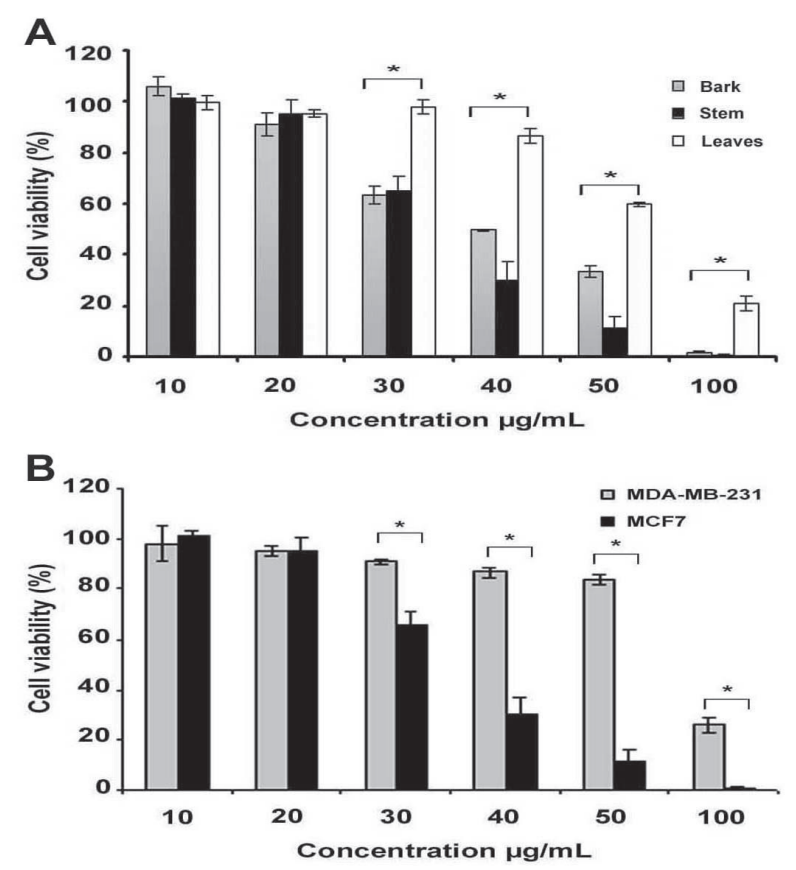

Figure 3. Cell viability studies of Syzygium aromaticum extracts on MCF-7 and MDA-MB-231 breast cancer cells. Dose dependent reduction of viability of MCF-7 cells by treatment with the bark, stem and leaves extracts (A). Stem extract shows dose dependent and selective inhibitory effect on the growth of MCF-7 cells compare to MDA-MB-231 cells (B). (*) indicates $p$ values $<0.05$.

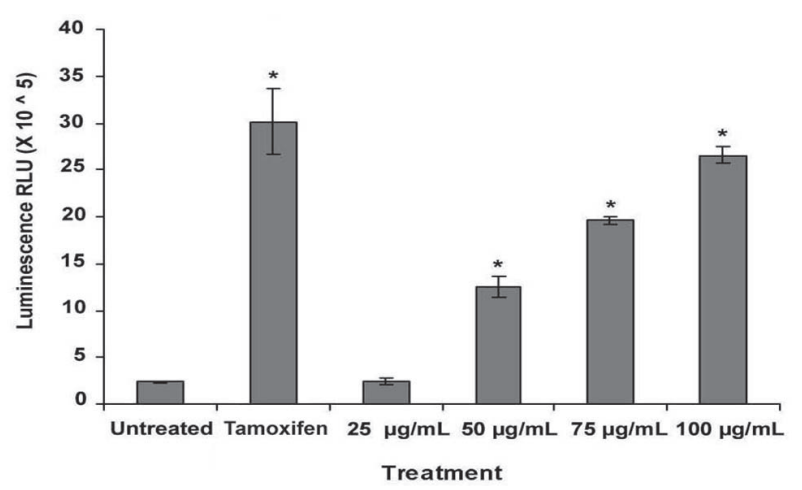

Figure 4. Apoptosis studies on MCF-7 cell by the caspases $3 / 7$ test. Chart showing dose dependent activation of caspases $3 / 7$ by the stem extract of Syzygium aromaticum after $6 \mathrm{~h}$ treatment. Tamoxifen at $10 \mu \mathrm{g} / \mathrm{mL}$ was used as a positive control. (*) indicates $p$ values $<0.05$.

\section{Combination study with tamoxifen}

The effect of simultaneous treatment of the extract at $25 \mu \mathrm{g} / \mathrm{mL}$ and tamoxifen at $10 \mu \mathrm{g} / \mathrm{mL}$ is presented in Figure 6A. Treatment of MCF-7 cells with tamoxifen and the extract alone resulted in $98 \pm 1 \%$ and $-4 \pm 4 \%$ inhibition, respectively. Simultaneous treatment of MCF-7 with both reagents reduced the percent of inhibition to $48 \pm 6 \%$.

Treatment of MCF-7 cells with tamoxifen at 10 $\mu \mathrm{g} / \mathrm{mL}$ for $24 \mathrm{~h}$ followed by treatment with the extract at $25 \mu \mathrm{g} / \mathrm{mL}$ reduced the percent of inhibition of tamoxifen from $100 \pm 1 \%$ to $42 \pm 0.1 \%$ (Figure 6B). Likewise, treatment of MCF-7 cells with the extract at $25 \mu \mathrm{g} / \mathrm{mL}$ for $24 \mathrm{~h}$ followed by treatment with tamoxifen at 10 $\mu \mathrm{g} / \mathrm{mL}$ reduced percent of inhibition of tamoxifen from $98 \pm 1 \%$ to $30 \pm 1 \%$ (Figure $6 \mathrm{C}$ ). Simultaneous treatment of MCF-7 cells with tamoxifen at $5 \mu \mathrm{g} / \mathrm{mL}$ and different concentrations of extract $(50,40$ and $25 \mu \mathrm{g} / \mathrm{mL})$ did not show antagonistic effect. On the contrary, remarkable enhancement of the activity was observed particularly with the extract at $25 \mu \mathrm{g} / \mathrm{mL}$ (Figure 6D).

\section{Discussion}

In the present study, we report the presence of high concentration of BA, UA and OA in SA extracts and we describe a simple process to prepare BA fraction from the leaves extract without the use of column chromatography. Then we investigated the anti-breast cancer effect of the extracts on two breast cancer cells MCF-7 and MDA-MB-231.

Cytotoxic effect of the extracts was first evaluated on the hormone dependent MCF-7 cells, the results indicate the stem extract to be the most potent and selective. Even though the leaves extract shows the highest levels of BA $(17 \% \mathrm{wt} / \mathrm{wt})$, it showed the least cytotoxic effect on MCF-7. Likewise BA fraction showed a mild cytotoxicity on MCF-7. Taken together we can conclude that the reported cytotoxicity on MFC-7 cells is not due to presence of BA but due to other compounds. Afterwards, we studied the apoptotic potential of the stem extract on MCF-7 targeting two apoptosis markers viz. caspases 3/7 as early markers and chromatin condensation as a late marker of apoptosis. The stem extract caused activation of the apoptotic machinery of cell death by activating caspases 3/7 and also caused chromatin condensation and nuclear fragmentation in the MCF-7 cells. In order explore the anti-estrogen potential of the extract we studied the cytotoxicity on a hormone resistant breast cancer cell line MDA-MB-231. The results show that the extract is two times more cytotoxic on MCF-7 than MDA-MB-231 cells. This result further suggests the potential anti-estrogen effect of the extract.

Combination of the stem extract at $25 \mu \mathrm{g} /$ $\mathrm{mL}$ with tamoxifen at $10 \mu \mathrm{g} / \mathrm{mL}$ caused reduction of cytotoxic effect of tamoxifen on MCF-7 cells by half suggesting antagonistic activity. Likewise sequential treatment of MCF-7 cells with tamoxifen and the extract resulted in less cytotoxicity than tamoxifen alone. 

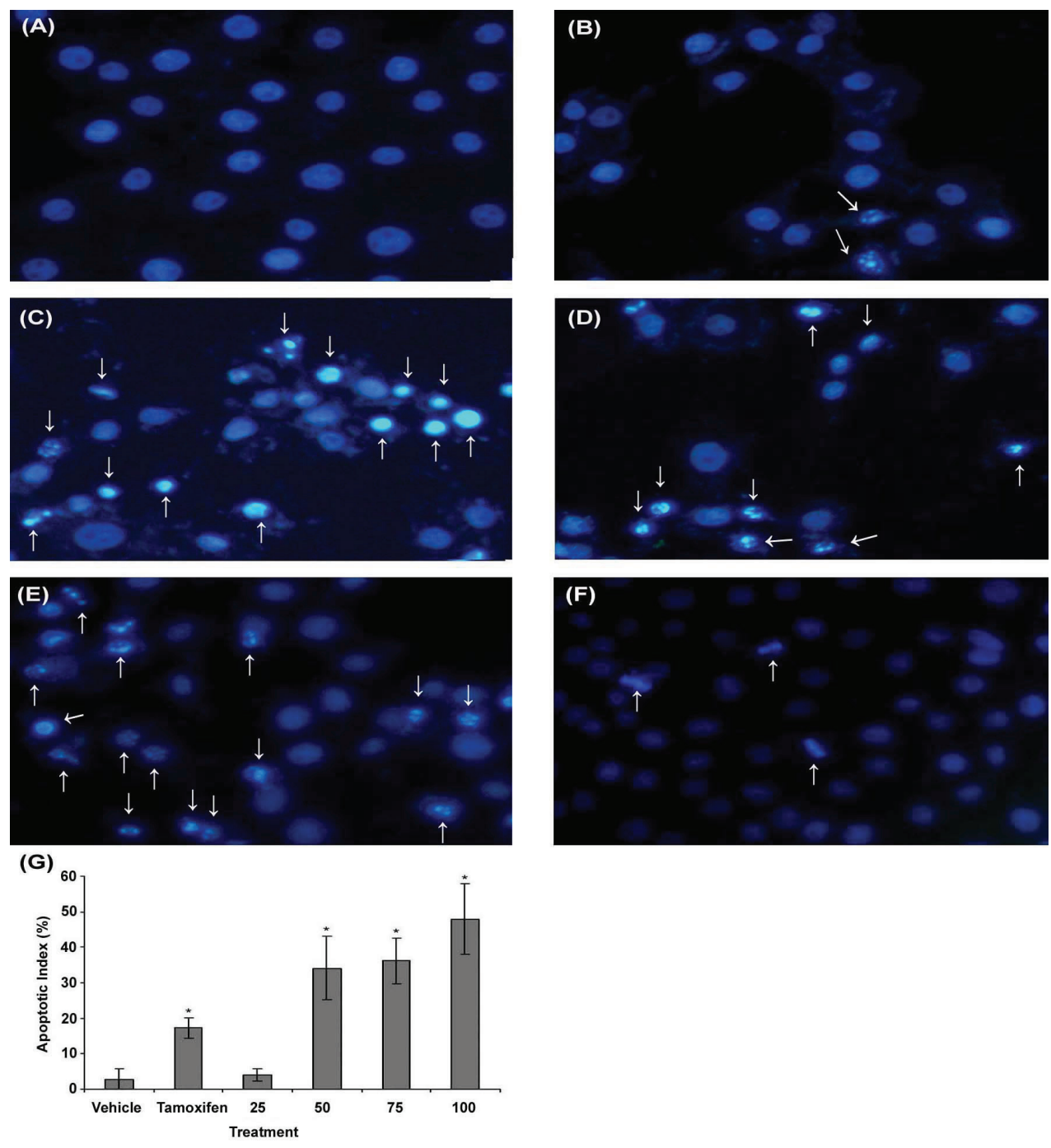

Figure 5. Apoptosis studies on MCF-7 cells by nuclear staining with Hoechst 33258. Untreated cells showing uniform nuclear staining (A), cells treated with tamoxifen at $10 \mu \mathrm{g} / \mathrm{mL}$ (B). C-F, cells treated with stem extract of Syzygium aromaticum at $100 \mu \mathrm{g} /$ $\mathrm{mL}(\mathrm{C}), 75 \mu \mathrm{g} / \mathrm{mL}$ (D), $50 \mu \mathrm{g} / \mathrm{mL}$ (E), and $25 \mu \mathrm{g} / \mathrm{mL}$ (F). Calculated apoptotic index (G). The arrows indicate apoptotic cells and the $(*)$ Indicates $p$ values $<0.05$.

However, combination of different concentrations of the extract $(50,40$ and $25 \mu \mathrm{g} / \mathrm{mL})$ with low concentration of tamoxifen $(5 \mu \mathrm{g} / \mathrm{mL})$ did not show any antagonistic activity but at $5 \mu \mathrm{g} / \mathrm{mL}$ of tamoxifen and $25 \mu \mathrm{g} / \mathrm{mL}$ of the stem extract, a marked improvement in cytotoxic activity was observed. In conclusion, the stem extract of S. aromaticum can enhance the cytotoxicity of tamoxifen at low concentration of the drug against MCF-7 but at high concentration it has strong antagonistic effect.

SA has two potential medicinal applications the first one is providing a source for BA and other triterpenes which were reported to have anticancer, antiinflammatory, antiangiogenic and other pharmacological properties. The second potential application is the synergistic effect with tamoxifen and the potential preventive effects on breast cancer.

\section{Acknowledgements}

This work received funds from Universiti Sains Malaysia, science fund number 305/PFARMASI/613219 and by FRGS-MOE fund number 203/PFARMASI/61154. The project was also funded by the research chair of King Saud University on drug targeting and treatment of cancer using nanoparticles. The first author would like to acknowledge with thanks Universiti Sains Malaysia for providing a scholarship under the fellowship program for 2010, reference number P-FD0010/08(R). The authors would like to express their thanks and appreciation to $\mathrm{Mr}$. Shanmugan A/C Vellosamy for his role in identification the plant material. 


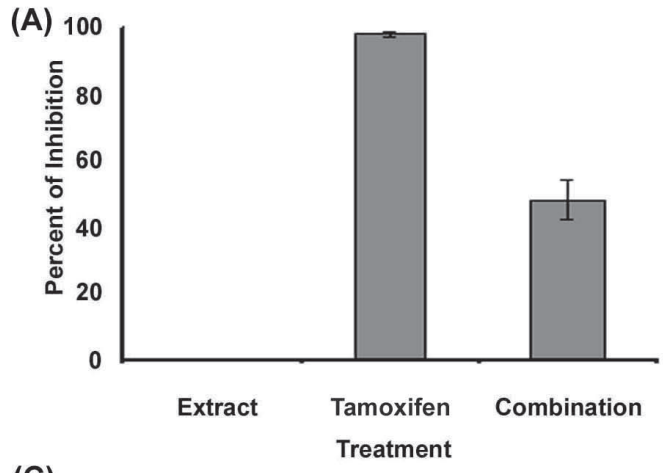

(C)

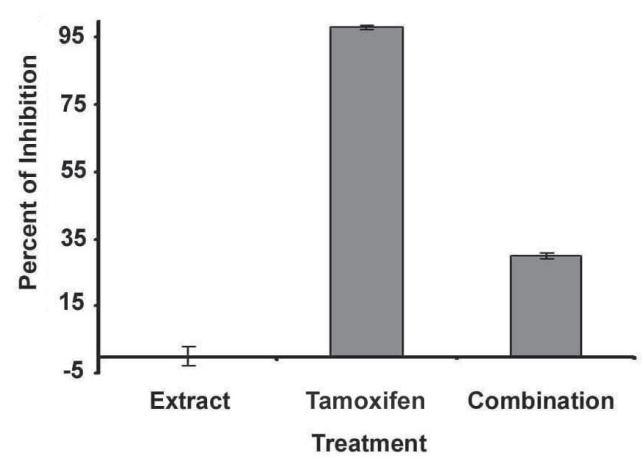

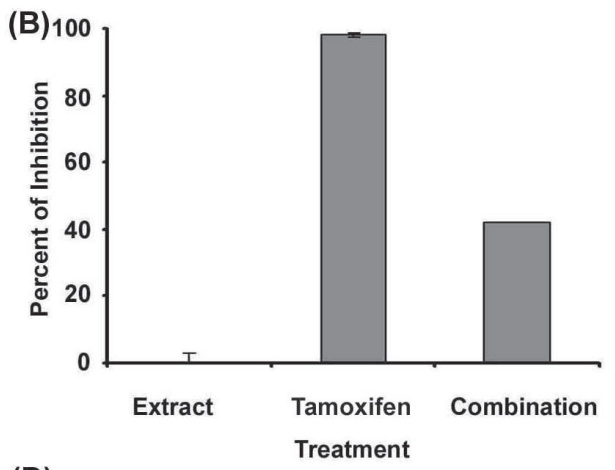

(D)

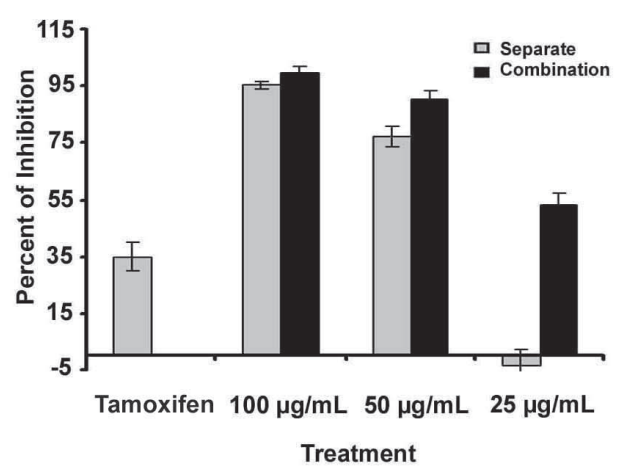

Figure 6. Combination studies of Syzygium aromaticum stem extract and tamoxifen by XTT assay. Simultaneous treatment with extract at $25 \mu \mathrm{g} / \mathrm{mL}$ and tamoxifen at $10 \mu \mathrm{g} / \mathrm{mL}$ (A). Sequential treatment with tamoxifen at $10 \mu \mathrm{g} / \mathrm{mL}$ for $24 \mathrm{~h}$ followed by treatment with the extract at $25 \mu \mathrm{g} / \mathrm{mL}$ for another $24 \mathrm{~h}$ (B). Sequential treatment with the extract at $25 \mu \mathrm{g} / \mathrm{mL} \mathrm{for} 24 \mathrm{~h}$ followed by treatment with tamoxifen at $10 \mu \mathrm{g} / \mathrm{mL}$ for another $24 \mathrm{~h}(\mathrm{C})$. Simultaneous treatment with extract at different concentrations and tamoxifen at $5 \mu \mathrm{g} / \mathrm{mL}$ (D).

\section{References}

Aisha AFA, Nassar ZD, Siddiqui MJ, Abu-Salah KM, Alrokayan SA, Ismail Z, Abdul Majid AMS 2011. Evaluation of antiangiogenic, cytotoxic and antioxidant effects of Syzygium aromaticum L. extracts. Asian J Biol Sci 4: 282-290.

Aisha AFA, Abu-Salah KM, Darwis Y, Abdul Majid AMS 2009a. Screening of antiangiogenic activity of some tropical plants by rat aorta ring assay. Int $J$ Pharmacol 5: 370-376.

Aisha AFA, Alrokayan SA, Abu-Salah KM, Darwis Y, Abdul Majid AMS 2009b. In vitro cytotoxic and apoptotic properties of the stem bark extract of Sandoricum koetjape on breast cancer cells. Int $J$ Cancer Res 5: 123-129.

Banerjee S, Panda CK, Das S 2006. Clove (Syzygium aromaticum L.), a potential chemopreventive agent for lung cancer. Carcinogenesis 27:1645-1654.

Chaieb K, Hajlaoui H, Zmantar T, Kahla-Nakbi AB, Rouabhia M, Mahdouani K, Bakhrouf A 2007. The chemical composition and biological activity of clove essential oil, Eugenia caryophyllata (Syzigium aromaticum L.
Myrtaceae): a short review. Phytother Res 21:501-506. Cheah YH, Azimahtol HL, Abdullah NR 2006. Xanthorrhizol exhibits antiproliferative activity on MCF-7 breast cancer cells via apoptosis induction. Anticancer Res 26: 4527-4534.

Chen J, Peng H, Ou-Yang X, He X 2008. Research on the antitumor effect of ginsenoside Rg3 in B16 melanoma cells. Melanoma Res 18: 322-329.

Darshan S, Doreswamy R 2004. Patented antiinflammatory plant drug development from traditional medicine. Phytother Res 18: 343-357.

Fujioka T, Kashiwada Y, Kilkuskie RE, Cosentino LM, Ballas LM, Jiang JB, Janzen WP, Chen I-H, Lee K-H1994. Anti-AIDS agents, 11. Betulinic acid and platanic acid as anti-HIV principles from Syzigium claviflorum, and the anti-HIV activity of structurally related triterpenoids. J Nat Prod 57: 243-247.

Fulda S 2008. Betulinic acid for cancer treatment and prevention. Int J Mol Sci 9: 1096-1107.

Jäger S, Trojan H, Kopp T, Laszczyk MN, Scheffler A 2009. Pentacyclic triterpene distribution in various plants - rich sources for a new group of multi-potent plant extracts. Molecules 14: 2016-2031. 
Jost L, Kirkwood J, Whiteside T 1992. Improved short- and long-term XTT-based colorimetric cellular cytotoxicity assay for melanoma and other tumor cells. J Immunol Methods 4: 153-165.

Miyazawa M, Hisama M 2001. Suppression of chemical mutagen induced SOS response by alkylphenols from clove (Syzygium aromaticum) in Salmonella typhymurium TA1535/pSK1002 umu test. J Agr Food Chem 49: 4019-4025.

Mukherjee R, Jaggi M, Rajendran P, Siddiqui MJA, Srivastava SK, , Vardhan A, Burman AC 2004. Betulinic acid and its derivatives as anti-angiogenic agents. Bioorg Med Chem Lett 14: 2181-2184.

Mutai C, Bii C, Rukunga G, Ondicho J, Mwitari P, Abatis D, Vagias C, Roussis V, Kiruic J 2009. Antimicrobial activity of pentacyclic triterpenes isolated from Acacia Mellifera. Afr J Tradit Complement Altern Med 6: 4248.

Ogata M, Hoshi M, Urano S, Endo T 2000. Antioxidant activity of eugenol and related monomeric and dimeric compounds. Chem Pharm Bull 48: 1467-1469.

Prashar A, Locke IC, Evans CS 2006. Cytotoxicity of clove (Syzygium aromaticum) oil and its major components to human skin cells. Cell Prolif 39: 241-248.

Pavlovaa NI, Savinovaa OV, Nikolaevaa SN, Boreko EI, Flekhterb OB 2003. Antiviral activity of betulin, betulinic and betulonic acids against some enveloped and non-enveloped viruses. Fitoterapia 74: 489-492.

Srivastava P, Chaturvedi R 2010. Simultaneous determination and quantification of three pentacyclic triterpenoidsbetulinic acid, oleanolic acid, and ursolic acid in cell cultures of Lantana camara L. In Vitro Cell Dev Biol Plant 46: 549-557.

Tajuddin S, Ahmad A, Latif, Qasmi IA 2004. Effect of 50\% ethanolic extract of Syzygium aromaticum (L.) Merr. \& Perry. (clove) on sexual behaviour of normal male rats. BMC Complement Altern Med 5: 4-17.

Trongtokit Y, Rongsriyam Y, Komalamisra N, Apiwathnasorn C 2005. Comparative repellency of 38 essential oils against mosquito bites. Phytother Res 19: 303-309.

Zheng GQ, Kenney PM, Lam LKT 1992. Sesquiterpenes from clove (Eugenia caryophyllata). J Nat Prod. 55: 9991003.

Viji V, Shobha B, Kavitha SK, Ratheesh M, Kripa K, Helen A 2010. Betulinic acid isolated from Bacopa monniera (L.) Wettst suppresses lipopolysaccharide stimulated interleukin-6 production through modulation of nuclear factor-kappaB in peripheral blood mononuclear cells. Int Immunopharmacol 10: 843-849.

\section{*Correspondence}

Amin Malik Shah Abdul Majid

School of Pharmaceutical Sciences, Universiti Sains Malaysia Minden 11800, Pulau Pinang, Malaysia

aminmalikshah@usm.my

Tel.: +60 46534582

Fax: +6046534582 